Article

\title{
The Perspective of E-Business Sustainability and Website Accessibility of Online Stores
}

\author{
Carmen Adina Paștiu ${ }^{1} \mathbb{D}$, Ionica Oncioiu ${ }^{2, *} \mathbb{B}$, Daniel Adrian Gârdan ${ }^{3}$, \\ Silvia Ștefania Maican ${ }^{1}$, Iuliana Petronela Gârdan ${ }^{3}\left[\right.$ and Andreea Cipriana Muntean ${ }^{1}$ \\ 1 Faculty of Economic Sciences, 1 Decembrie 1918 University, 510009 Alba-Iulia, Romania; \\ carmenpastiu@yahoo.com (C.A.P.); sylvia.maican@gmail.com (S.S.M.); \\ munteanadreea2009@yahoo.com (A.C.M.) \\ 2 Faculty of Finance-Banking, Accountancy and Business Administration, Titu Maiorescu University, \\ 040051 Bucharest, Romania \\ 3 Faculty of Economic Sciences, Spiru Haret University, 060821 Bucharest, Romania; \\ danielgardan@gmail.com (D.A.G.); gardanpetronela@yahoo.com (I.P.G.) \\ * Correspondence: ionicaoncioiu@yahoo.ro or ionica.oncioiu@prof.utm.ro
}

Received: 17 October 2020; Accepted: 20 November 2020; Published: 23 November 2020

\begin{abstract}
E-commerce's latest trends, highlighted by the global phenomena of the COVID-19 pandemic, explicitly show substantial changes in the online consumers' behavior as well. More and more specialists are talking about the emergence of a new paradigm in consumption, and of possible evolutions toward sustainable consumption. The purpose of this research is to investigate how the antecedents of e-loyalty have changed their effect on consumer attitudes and perceptions of e-commerce sites. The results, obtained through a structural model of 523 validated questionnaires of Romanian consumers of electronic and household appliances, show the importance of the effect of website accessibility, a factor that, until recently, exerted an influence mediated by other elements grouped either under the umbrella of site quality or site design. The model validated after the analysis shows the direct effect of the accessibility of the websites on e-loyalty, satisfaction and trust of the consumers. Based on the results, the value of this study lies in the fact that it presents arguments on how the boost of e-commerce systems leads to sales processes' sustainability improvement and, to the same extent, the improvement of the ways for reporting sustainability using IT tools (online databases with customers, software integrated into e-commerce platforms, electronic financial management).
\end{abstract}

Keywords: e-business; website accessibility; e-loyalty; consumer behavior in e-commerce; sustainability; online stores

\section{Introduction}

The e-economy is a business economy that includes all types of businesses built around the Internet in connection with other large-scale and impactful processes such as innovation, globalization and sustainable development [1-4]. At the same time, the increase in the volume of e-commerce activity is currently an indisputable reality. According to the values forecast by eMarketer, there is an increase in the volume of e-commerce activity by $14.1 \%$ in 2019 compared to 2018 , and by $16.1 \%$ in 2020 compared to 2019, reaching the value of $\$ 4206$ trillion, which indicates that e-commerce is gaining ground over offline retail [5]. In the current conditions, caused by the COVID-19 pandemic, the increase of online consumption is assured as an important trend that will characterize the world economy for some time from now on [6].

Increasing the volume of online demand does not automatically mean a decrease in competitive pressure. This will certainly be maintained, and for certain products and services, there will even be an 
increase in this pressure. The change of the consumers' lifestyle, the adaptation to the requirements imposed by the states of emergency or necessity established by governments led to the proliferation of online orders and the intense use of deep distribution channels with the delivery of products directly to the customer's location. These changes are equally accompanied by important changes in trade policies and the activity of retailers-large or small [7-9].

The norms imposed by the companies' authorities meant the closure of some stores with large exhibition and sales spaces or their adaptation for order lifting systems. Thus, we are facing unprecedented challenges-online activity, with all services included-product search, booking, ordering, and delivery, etc., has become extremely important for both parties (seller and buyer), being the only viable and legally agreed option in conditions of necessity. All of this creates a complex picture that makes consumer loyalty extremely important in the online environment.

To the above can be added the fact that, in recent years, consumers have an increasing ability to identify on the Internet information about the products sought and the ability to compare in real-time the various benefits and offers $[10,11]$. This behavior is an additional cause for the tendency of consumers to decrease the level of loyalty to e-commerce websites [12-14].

Unlike traditional commerce, e-commerce websites face stiff competition due to the ease with which consumers can interact with technology, which also contributes to the need for online retailers to focus on loyalty strategies [15].

The present study aims to highlight the antecedents of e-loyalty for a specific category of products on the market-electronic products-and to explore the correlations that occur between the determinants of e-loyalty. The research carried out on Romanian consumers highlights the influence of site accessibility on satisfaction mediated trust, and, surprisingly, the influence of the same accessibility on loyalty toward the online store's website. Additionally, the model proposed and validated through the research indicates the direct relationship of satisfaction with e-loyalty and also its relationship mediated by trust.

Therefore, this study makes an important contribution to the highlighted correlations and supports the idea that the behavioral models modified in the conditions of the COVID-19 pandemic are built on arguments that reflect substantial changes in the role that various factors have on consumption. In particular, this study is important because online customers are very rational in the digital era and they want online electronic and household appliances that give them maximum utility. Increasing the accessibility of websites means optimizing them both in terms of design, functionality and browsing experience, which leads to the promotion of a sustainable online shopping behavior. The results of this study also show that the quality of online electronic and household appliances has a significant effect on customers' intention to use the website. The strong development of online shopping interfaces boosts the sustainability of business processes and their positive evolution, as well as the ways of reporting it. High-performance e-commerce systems allow real-time monitoring and reporting of all customer operations, including the generation of consumer profiles highlighting their loyalty.

This article is structured as follows. The second section presents conceptual approaches to the literature review and the development of the hypothesis; the third section provides the research model and methodology; the next sections describe the empirical results and implications for the discussions. The conclusions of the study are outlined in the final part.

\section{Theoretical Framework and Hypothesis Development}

E-commerce sustainability refers mainly to three different dimensions that are actually intrinsic for the very concept of sustainability: environmental side of e-commerce, the economic side and the social side [16-20]. Every dimension has to be carefully assessed as there are different aspects that can be highlighted as consequences of e-commerce development upon sustainability dimensions. From the point of view of economic dimension of e-commerce sustainability, which is for many specialists, the most visible one, we can talk about operational and innovation performance, better ways to implement differentiation from competition, reduced time to market products, improvements in assets 
utilization and a visible and better flexibility of companies in their effort to respond to customers' demands [16-18]. From the point of view of social dimension of e-commerce sustainability, it is evident that the capability of e-commerce to help the improvement of social innovation, referring, at the same time, to the improvement of life conditions for individuals or the basic needs of the society as whole $[16,19,20]$.

Previous research reveals that the environmental dimension of e-commerce sustainability is the most disputed one as the advantages and disadvantages directly connected with the e-commerce activity are hard to compare in an objective manner $[1,4,7,16,17]$. On one hand, there are positive trade-offs related with the reduction of individual consumers' travels and emissions, and the use of green initiatives for transportation of goods in the case of some e-commerce companies; on the other hand are the negative effects over the environment due to the increased number of shipments and transportations, increased number of packaging types and volume, and minimum compliance to laws and regulations forced by some e-commerce-involved companies, etc.

Additionally, e-commerce sustainability can be considered a reality only with the help of collaboration between all the stakeholders in the virtual market and a responsible common agenda [20]. At the same time, companies must deal with a series of trade-offs between the different dimensions like: social-economic; economic-environmental; and environmental-social. However, e-commerce sustainability is strongly related with the capacity of companies to remain competitive and to attract and retain more consumers within the virtual marketplace. Developing loyalty within the online environment presupposes a nuanced approach, even though many studies are considering e-loyalty as an extension of offline loyalty [21,22].

Specifically, e-loyalty, within a behavioral approach, can be defined from two perspectives. The first one is actually related with the products, services, or brands per se, being the intention to repurchase the product, the service or the brand, and to recommend it through the web, social networks, or mobile phone. The repurchase can be done also through other sites compared to the original one. There is a product/brand-centered process when the loyalty state of mind is constructed around the very characteristics and attributes of the product or service itself, using websites just as a means to reach the products and transfer information to complete the buying process. The second one is related to the website being the intention to repurchase on the same website and to recommend it through different online or mobile channels even if it is not the same product [23-25]. In this case, we speak about loyalty toward the website itself.

To obtain a broader view about e-loyalty, it is necessary to refer to the different stages regarding the conceptualization of loyalty itself, as it can be useful to assess also the attitudinal dimension of loyalty, not only the behavioral one. Different authors are stressing the importance of attitudinal dimension-loyalty being considered also the result of a psychological process that favors a positive attitude toward a certain brand or product [26-29]. Thus, taking into account both the behavioral and attitudinal dimensions into the measurement process of loyalty is a plus if we want to gain a proper view of the matter. Therefore, we can also consider e-loyalty "a customer's favorable attitude toward the e-retailer that results in repeat buying behavior" [30]. Antecedents for e-loyalty are considered to be customization, contact interactivity, care, community, choice, convenience, e-trust, e-satisfaction and e-commitment [31,32].

To assess the factors that have a positive influence over e-loyalty in the present context of online consumer behavior, we propose a short analysis of some of the evolutions that are relevant for the specific online environment of today [33].

In this study, we start our endeavor from the perspective of online consumption experience drivers that are prevailing in the context of economic or social crisis. Consumers can develop strong hedonic-type motives of consumption related to online buying (enduring involvement, visual appeal, sensation seeking, escape, intrinsic enjoyment, hang out, socialization, self-expression and role shopping) [33-37]. 
Consumers tend to transform the online buying experience and Internet navigation, in general, into a hedonic-type consumption experience that is capable to counterbalance the social pressure and stress that can be overwhelming during an economic and social crisis like the one that we are facing today [38-40].

In this context, every factor that can contribute to easy access and easy navigation in the online environment acquires considerable importance $[7,17,22]$.

If, for a consumer accustomed to the online environment who has a "classic" buying behavior, the accessibility of the website was an important but not decisive attribute for the purchase decision and even less for his loyalty to the site or the appearance/development of trust, for "new" consumers, it would seem that accessibility becomes a variable that directly influences trust and loyalty to the site.

This can be explained by the fact that this new type of consumer can be associated with the profile of a consumer who is put in the situation of accepting the e-commerce system as a necessity imposed by the nature of events (restriction for the offline sale/purchase of goods). Thus, accessibility is seen as a basic attribute, easy to understand by this type of consumer, and dominant in his perception of the idea of "successful online shopping".

People, in COVID-19 pandemic conditions, are looking for quick and convenient solutions at their fingertips [40]. Thus, website accessibility is defined as such: the ease with which they can navigate, they can effectively order the desired product and can see the whole process completed or resumed without too much hassle. Such a website becomes, for this consumer that has a lack of experience and resilience in the online environment, the saving solution and the ideal site to which his long-term loyalty can be directed.

The causal relationship between the variable accessibility and trust is based on the same need for the new type of consumer-fast solutions, at hand, to be able to consume the necessary products in crisis conditions [23]. Thus, websites that invest enough in optimizing accessibility give the consumer the feeling that he is dealing with a reliable business, directly interested in his needs-the ease of accessing and placing orders and the reliability of the process.

On the other hand, the perception of accessibility naturally turns into appreciation on the degree of trust that can be invested in the website [7,22]. Moreover, in this case, we could add to the above the fact that, for the new type of online consumer, accessibility mainly creates a high level of satisfaction, against the background of its pressing need for safe and easy solutions for short-term consumption. In this context, we consider appropriate the relationship between site accessibility, satisfaction, trust, and e-loyalty in the form of the model presented in Figure 1.

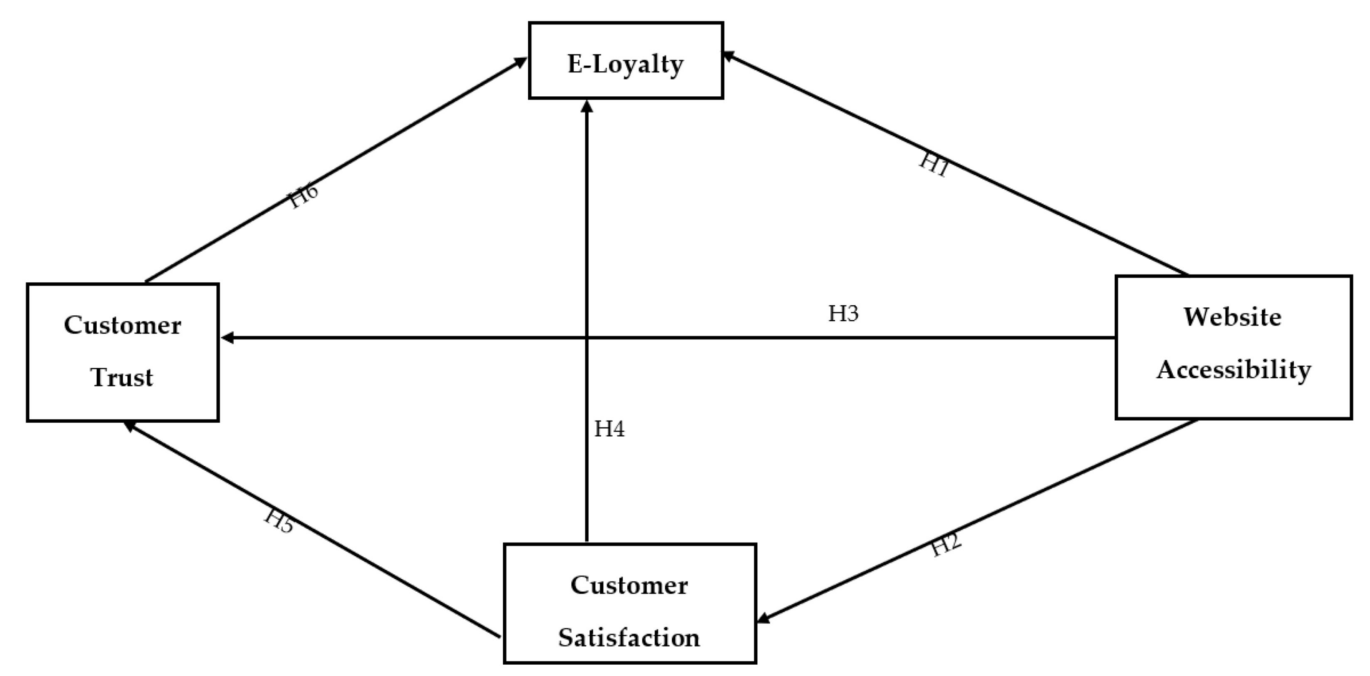

Figure 1. The proposed research conceptual model. 
As can be seen, the model is constructed upon certain relationships between considered variables. The first that came into our attention is the relationship between website accessibility and e-loyalty. Scientific literature shows different insights that put accessibility into a direct or mediated relation with e-loyalty [41-43]. Perceived ease of use features along with perceived usefulness features and trust features regarding a website has been used to build the e-loyalty which is seen as a continued intention factor [43-45].

Other research points out nine independent variables that have a direct effect on customer loyalty and satisfaction, among them being cited "ease of use" and accessibility/convenience [46].

In many contexts, accessibility is an element analyzed under the umbrella of a website's quality concept [47-49]. However, the quality of websites creates e-loyalty mediated by e-satisfaction and/or e-trust. Results studies show that e-satisfaction, e-trust, and switching barriers have a direct effect on e-loyalty. Additionally, e-trust creates e-loyalty with e-satisfaction as a mediator; and the quality of the website creates e-loyalty as mediated [49-52].

The importance of the website's accessibility can be also seen from the perspective of a parallel made with the traditional brick and mortar store's atmospherics. The retailers in the online environment have to build the same presence embedded into websites, like in the case of offline stores, to gain customers' attention and willingness [53,54]. Website accessibility can be considered one of the most important elements capable of contributing to that online positive experience [55-57].

The information displayed on websites positively and significantly determines shoppers' loyalty towards an online retail store (seen as the "the customer's favorable attitude toward an electronic business resulting in repeat buying behavior"); more precisely, utilitarian value, web informativeness, the effectiveness of information content and web entertainment are also having a positive and significant influence on e-satisfaction $[15,28,33]$.

The research has shown that websites which have a proper web design and well-managed information content, which is easy to find, would enhance shoppers' satisfaction and loyalty towards the site. Shoppers in an online shopping environment are needing proper, relevant, and easy to find information, otherwise, they can move to a competitor or even quit online shopping. Thus, online retailers' websites must be equipped with relevant and easily locatable information [55]. In the context of the Internet-enabled logistics supply chain, this shows that the websites' ease of use increases consumers' ability to locate merchandise, with just a click of the mouse [58]. Easy access to rich information is becoming an antecedent to e-loyalty and increases the efficiency of online buying decisions [59]. On all the above considerations, we propose the first research hypothesis:

Hypothesis 1 (H1). Website accessibility positively affects customer e-loyalty.

The second relationship within the proposed conceptual model of the research refers to the relation between website accessibility and customer satisfaction regarding website utilization. The e-satisfaction of customers is related to the affective state as a consequence of order fulfillment in a previous e-commerce transaction [60]. Online customer satisfaction can be an antecedent for future purchase intention and e-loyalty highlighting the experience of contentment [61]. Satisfaction will be related to the needs and expectations that have been crystallized after repeat online purchases materializing itself as a cumulative evaluation of a product or a service bought online [62].

In addition, website accessibility can be assimilated with the concept of convenience regarding websites' online consumption [61-63]. Thus, identifying key drivers for online customer convenience is of great importance. Online customer convenience will affect a lot of the customer's satisfaction; different studies show that a service convenience scale is useful to assess the overall customer satisfaction in the online setting [62]. Website accessibility can be properly assessed through attributes like-perception, operability, meaning, and robustness of the website content. Each of these elements are seen as determinants for the process of customer online satisfaction self-assessment [64,65]. Some authors have shown these antecedents of consumer e-satisfaction: website design, reliability, shopping values and 
customer service [15]. The same research also highlights important factors that influence e-satisfaction: utilitarian value, the effectiveness of information content and web entertainment. In light of the above findings, we derive the second hypothesis of the conceptual model of the research:

Hypothesis 2 (H2). Website accessibility positively affects customer satisfaction related to website utilization.

The third relationship proposed within the conceptual model refers to the relation between website accessibility and customer trust. E-trust represents a very important variable in the context of e-loyalty antecedents. As a concept, it was fully studied within the scientific literature regarding online stores, and the majority of specialists are agreed upon the fact that it is a basic variable to describe the proper foundation for the online buying decisional process. Mainly, e-trust was considered an attitude of individuals correlated with positive expectations and confidence in front of the risk associated with the exploitation of its vulnerabilities within the online setting [12].

Other studies are suggesting that the appropriate level of web design quality develops at the level of customer perception, the image of a reliable website $[35,42,53,58]$. This state of mind will provide positive feedback, helping customers to further enhance the perception of proper website security. In the process of assessing their level of satisfaction within the online setting, customers need to evaluate and also interpret online trust. A high degree of trust will reinforce the willingness to pursue a specific brand or website, making the customer believe that the online retailer will not develop a kind of opportunistic behavior [66].

An important observation concerns the dimensions that online trust can have in a specific online setting: a technical-based dimension consisting in the presentation of websites, website accessibility, ease of use for the technology; a dimension concerning the security of transactions and a dimension based on reputation-competencies, and capacity of real-time interaction, customer service, etc. [62].

As we highlighted earlier, website accessibility is analyzed many times under the concept of website quality along with other dimensions like design, content, functionality, etc. Customers' online trust will be built upon a different range of expectations—starting from user-friendly design, content accessibility and clear information structure.

According to the technology acceptance model (TAM), the perceived ease of use of a specific system (in our case, this could be a website and the hardware interface used to access it), can influence the intention of a person to use the specific system [67]. A free from effort online experience, characteristic for a website with a high degree of accessibility, will motivate the user to transact online. Along with the perception of usefulness and enjoyment of technology, the perceived ease-of-use will contribute to a higher degree of online trust and a stronger purchase intention [66]. Since many e-commerce website infrastructures fail to convince their customers that all transactions are $100 \%$ sure, a great number of users will still consider online purchasing risky. Their trust propensity will be an important determinant for their consumption motivation. Taking into consideration all the above, we posit the third hypothesis regarding the relationship between website accessibility and customer trust:

Hypothesis 3 (H3). Website accessibility positively affects customer trust.

The fourth relation within our conceptual model refers to a well-documented one within the literature-the relationship between satisfaction and e-loyalty. The majority of scholars consider satisfaction as being one of the most important antecedents for loyalty [15]. Evidence from various research shows that satisfied customers tend to use more services and involve themselves in a high level of consumption experiences with the same brands or the same website context [15,68]. An interesting finding into the context is one of that assesses the strength of the relationship between satisfaction and loyalty by depending upon the competitive structure of the industry $[68,69]$. Thus, we can provide the fourth hypothesis corresponding to the conceptual model of the research:

Hypothesis 4 (H4). Customer satisfaction positively affects customer e-loyalty. 
The fifth relationship that can be highlighted within the conceptual model is the one between customer satisfaction and customer trust $[12,49,62]$. Customer satisfaction represents an antecedent for customer trust. In the online environment, repeated levels of customer satisfaction make possible the positive attitude of the customers toward the website and contributes equally to a higher level of trust. We can assess a double type of relationship, developed in both directions-from customer satisfaction towards customer trust and from customer trust towards customer satisfaction. Once a customer gains sufficient trust after repeated purchases, we can talk about increased satisfaction also [62,68,70]. Still, in the online setting, the first direction taken into consideration-the influence from customer satisfaction toward customer trust-prevails because of the importance that trust has at the level of online consumption behavior. There are a lot of situations in which, when a consumer is satisfied with an online retailer, this became the basis for the perception regarding the level of trust that can be transferred upon the retailer.

Moreover, other authors show that even if we talk about a level of brand familiarity higher or lower, the relationship between satisfaction and trust remains positive, with e-satisfaction acting like a source for e-trust [12,65]. Recent studies show that repeat online shopping satisfaction positively affects the intention to continuously use websites, giving birth to behavioral and attitudinal e-loyalty $[12,31,50,71]$. Taking account all the above, we propose the fifth hypothesis corresponding to the conceptual research model:

Hypothesis 5 (H5). Customer satisfaction positively affects customer trust.

The sixth relationship present within the conceptual model stresses the bond between two very important variables that are used to explain online consumer behavior-e-trust and e-loyalty. From this point of view, different authors have analyzed this relationship over time, as trust along with satisfaction was considered a kind of "traditional" antecedent for loyalty. Satisfaction, together with trust, and switching barriers that can appear are having a direct effect on e-loyalty [50]. In the process of loyalty development, trust is considered a part of the attitudinal phase development of loyalty. Trust can be the perfect setting for a high level of affective commitment so that a strong bond between the two parts can be achieved. Moreover, research also shows that trust is an antecedent for conative loyalty within the online setting [72].

The positive relationship between trust and satisfaction influence, to a high degree, e-loyalty, as it is functioning as a self-sustaining process capable of creating the special mindset necessary for the loyalty of the consumer-more trust creates the motivation to feel satisfied, more satisfaction gives the suitable reasons to trust the online retailer more and more as being capable to deliver a plus of value to the customer [68]. Besides trust, switching costs can also have a different contribution to e-loyalty. Especially in the case of the conative dimension of loyalty, trust can have a more powerful influence than switching cost upon e-loyalty [72]. E-trust can have the role to reduce the uncertainty of the users, making the effect of security issues or negative word of mouth to be less visible regarding the development of e-loyalty [12,71,72]. Taking account of these considerations, we formulated the final hypothesis corresponding to our conceptual model:

Hypothesis 6 (H6). Customer trust positively affects customer e-loyalty.

\section{Materials and Methods}

In order to properly substantiate the sampling process necessary for the research related to this article, we took into account other research approaches in the field of online shopping, statistically representative of the Romanian population.

Within research conducted by IRES (Romanian Institute for Evaluation and Strategy), with the theme: "Pandemic-Financial Behavior, Acquisitions and Savings", researchers have used a multi-layered, probabilistic sample comprising 1055 individuals, that was representative at a national 
level [73]. Results have shown a degree of penetration for online buying of about $48 \%$. Within the sample considered, the subsample of the people that are buying from the Internet shows a percent of $92 \%$ within the category between 18-35 years of age, followed by $56 \%$ from the category of $36-50$ years of age. Regarding the level of education, $87 \%$ from the category of graduates or master students are buying online, followed by $52 \%$ of the respondents from the high school-level category.

The results regarding the structure of online buying show a degree of $81 \%$ of the total regarding household appliances, followed by clothing and accessories $71 \%$, shoes by $67 \%$, household maintenance products $57 \%$ and cosmetics $50 \%$. Regarding home delivery services, the numbers showed $17 \%$ of consumers have used them, from which $60 \%$ were using cooked food, $53 \%$ food, $36 \%$ non-food products and $13 \%$ drugs [73].

The above mentioned stand as arguments for the relevance of our study and the research context regarding the Romanian market. Taking account of the results above, there have been selected individuals from three large university campuses representative at the national level, from Bucharest, Alba Iulia and Sibiu. Several self-report electronic questionnaires to the total of 600 have been distributed during March 2020 and 523 valid questionnaires were returned which means a response rate of $87 \%$.

Every question within the questionnaire was derived from the hypothesis and objectives of the research, taking account also the measurement for the identified variables. The categorical variables are comprised in separate questions used to describe the structure of the sample and to sustain different correlations that can be made between independent variables and the dependent ones. For this study, the responses have been assessed on 7-point Likert type scales ranging from $1=$ strongly disagree to $7=$ strongly agree.

Participants were asked to rate their level of opinion regarding their e-loyalty about online shops. The survey contains measures of e-loyalty, trust, satisfaction and website accessibility. The variables were measured with 5 items, each synthesized with the help of a meta-analysis as can be seen in the introduction of the article.

Regarding the demographics, our sample comprises $42 \%$ males and $58 \%$ females; $54 \%$ are between 18 and 29 years old and $46 \%$ between 30 and 49 years old; $75 \%$ with higher education, $25 \%$ with secondary education completed at the time of research (considering that the sample refers to the people from university campuses, it results that $75 \%$ are students from the master's programs).

\section{Results}

To create the model dimensions (e-loyalty, trust, satisfaction and accessibility), a method exploratory factor analysis was initially used-the procedure that is known as the analysis of main components. This procedure will help us to identify the component variables that could be removed from the analysis to reduce the information that must be analyzed without affecting the accuracy of the final result. For each factor, the Cronbach's alpha coefficient was calculated to measure the internal consistency.

Although there is no standard value that a Cronbach's alpha coefficient should have to indicate the fidelity of the corresponding measurements, most researchers consider that for this coefficient, the values $\geq 0.90$ are excellent, $\geq 0.80$ are good, $\geq 0.70$ are acceptable [74,75].

It can be seen, according to Table 1, that all the values of the Cronbach's alpha coefficient are above 0.90 , which means that the fidelity (consistency) of the scales for each factor (latent variable) is confirmed.

In the case of the Kaiser-Meyer-Olkin (KMO) test for measuring the suitability of the sample, it must have a minimum workload of 0.5 to consider that sample size is appropriate for performing the factor analysis [74]. 
Table 1. Values regarding exploratory factor analysis (values of Bartlett's Test of Sphericity, Kaiser-Meyer-Olkin test and Cronbach's alpha coefficient, for each dimension of the model, extracted and retained based on the considered items).

\begin{tabular}{ccccc}
\hline Test Statistic & E-Loyalty & Trust & Satisfaction & Accessibility \\
\hline Bartlett's Test of Sphericity & & & & \\
Approx. Chi-Square & 5280.48 & 8678.5 & 2926.57 & 3832.68 \\
df & 28 & 10 & 6 & 6 \\
Sig. & 0 & 0 & 0 & 0 \\
Kaiser-Meyer-Olkin Measure & 0.94 & 0.92 & 0.87 & 0.88 \\
of Sampling Adequacy & 0.96 & 0.99 & 0.97 & 0.98 \\
Cronbach's alpha & & & & \\
\hline
\end{tabular}

Kaiser Henry recommended the value of 0.5 as the minimum acceptable value, and values above 0.9 are considered to be excellent [76]. In the case of this test also, the values are coming close to 0.9 for all the variables, meaning that the identified model is very good.

Another condition to be able to apply exploratory type factorial analysis and the main components analysis procedure deals with homoscedasticity verification or homogeneity of variances by the Bartlett test. This test is sensitive to abnormalities. The Bartlett Test is used for the null hypothesis test that implies all population variations are equal, compared to the alternative hypothesis that assumes at least two are different. In other words, the Bartlett Test examines whether the correlation matrix of the investigated population is similar to the identity matrix. If the population correlation matrix resembles the identity matrix, then it means that each variable correlates poorly with all other variables [77-79]. This test is considered significant and the null hypothesis is rejected if $p<0.001$.

In the case of the present research, the probability of being wrong is very low $p<0.001$ (Table 1 ) for each latent variable, and the distribution $\chi^{2}$ is high, which means the null hypothesis that the correlation matrix does not differ from the identity matrix is rejected.

In conclusion, it can be stated that factor analysis can be used because the latent variables determined to start from the initial items are valid in terms of item commonality (Kaiser-Meyer-Olkin test), item sphericity (Bartlett Test) and measurement scale consistency (Cronbach's alpha).

A confirmatory factor analysis was conducted to assess e-loyalty antecedents regarding electronic and appliances online shops, using version 24.0 of the IBM-SPSS AMOS program.

Table 2 presented the goodness of fit, and we point out that indices of the structural model were satisfactory for the variables of trust, loyalty, satisfaction and accessibility (Chi-square-CMIN $=646.08$, $\mathrm{df}=183 ; p=0.00 ; \mathrm{GFI}=0.90 ; \mathrm{SRMR}=0.04, \mathrm{IFI}=0.98, \mathrm{NFI}=0.97, \mathrm{TLI}=0.98, \mathrm{CFI}=0.98, \mathrm{RMSEA}=0.07$ ).

Table 2. Fit indices for the model.

\begin{tabular}{cccccccc}
\hline Model & P & SRMR & GFI & RMSEA & PCLOSE & CFI & NFI \\
\hline Research obtained values & 0.00 & 0.04 & 0.90 & 0.07 & 0.00 & 0.98 & 0.97 \\
Theoretical statistical values & $<0.05$ & $<0.05$ & $>0.90$ & $<0.10$ & $<0.05$ & $>0.95$ & $>0.95$ \\
\hline Model & TLI & IFI & RFI & PGFI & PNFI & PCFI & \\
\hline Research obtained values & 0.98 & 0.98 & 0.97 & 0.71 & 0.85 & 0.85 & \\
Theoretical statistical values & $>0.95$ & $>0.90$ & $>0.90$ & $>0.50$ & $>0.50$ & $>0.50$ & \\
\hline
\end{tabular}

Comparing the values obtained in Table 3 with the limit values of each index, it can be stated that the proposed model is satisfactory in terms of statistical consistency [79-83]. 
Table 3. Standardized direct effect coefficient.

\begin{tabular}{cccccccc}
\hline Hypotheses & Intercept & $\begin{array}{c}\text { Dependent } \\
\text { Variables }\end{array}$ & $\boldsymbol{\beta}$ & S.E. & C.R. & $\boldsymbol{P}$ & $\begin{array}{c}\text { Hypothesis } \\
\text { Testing }\end{array}$ \\
\hline H1 & Accessibility & E-loyalty & 0.30 & 0.04 & $8.10^{* * *}$ & $* * *$ & supported \\
H2 & Accessibility & Satisfaction & 1.03 & 0.09 & $11.57^{* * *}$ & $* * *$ & supported \\
H3 & Accessibility & Trust & 1.01 & 0.09 & $11.49^{* * *}$ & $* * *$ & supported \\
H4 & Satisfaction & E-loyalty & 0.39 & 0.04 & $10.94^{* * *}$ & $* * *$ & supported \\
H5 & Satisfaction & Trust & 0.22 & 0.06 & $3.44^{* * *}$ & $* * *$ & supported \\
H6 & Trust & E-loyalty & 0.04 & 0.03 & $1.97^{* * *}$ & $0.04^{* *}$ & supported \\
\hline
\end{tabular}

Note: ${ }^{* *} p<0.05,{ }^{* * *} p<0.001$; statistical significance of parameter estimates test of the statistic critical ratio (C.R.) needs to be $> \pm 1.96[78,79]$.

Table 3 and Figure 2 illustrate e-loyalty antecedents considered within the conceptual model of the research: website accessibility, customer satisfaction and customer trust are valid measurements and have a significant impact on e-loyalty. Next, we present the fact that website accessibility has a direct positive and significant effect on e-loyalty $(\beta=0.30, p<0.001)$, which means that Hypothesis 1 is validated.

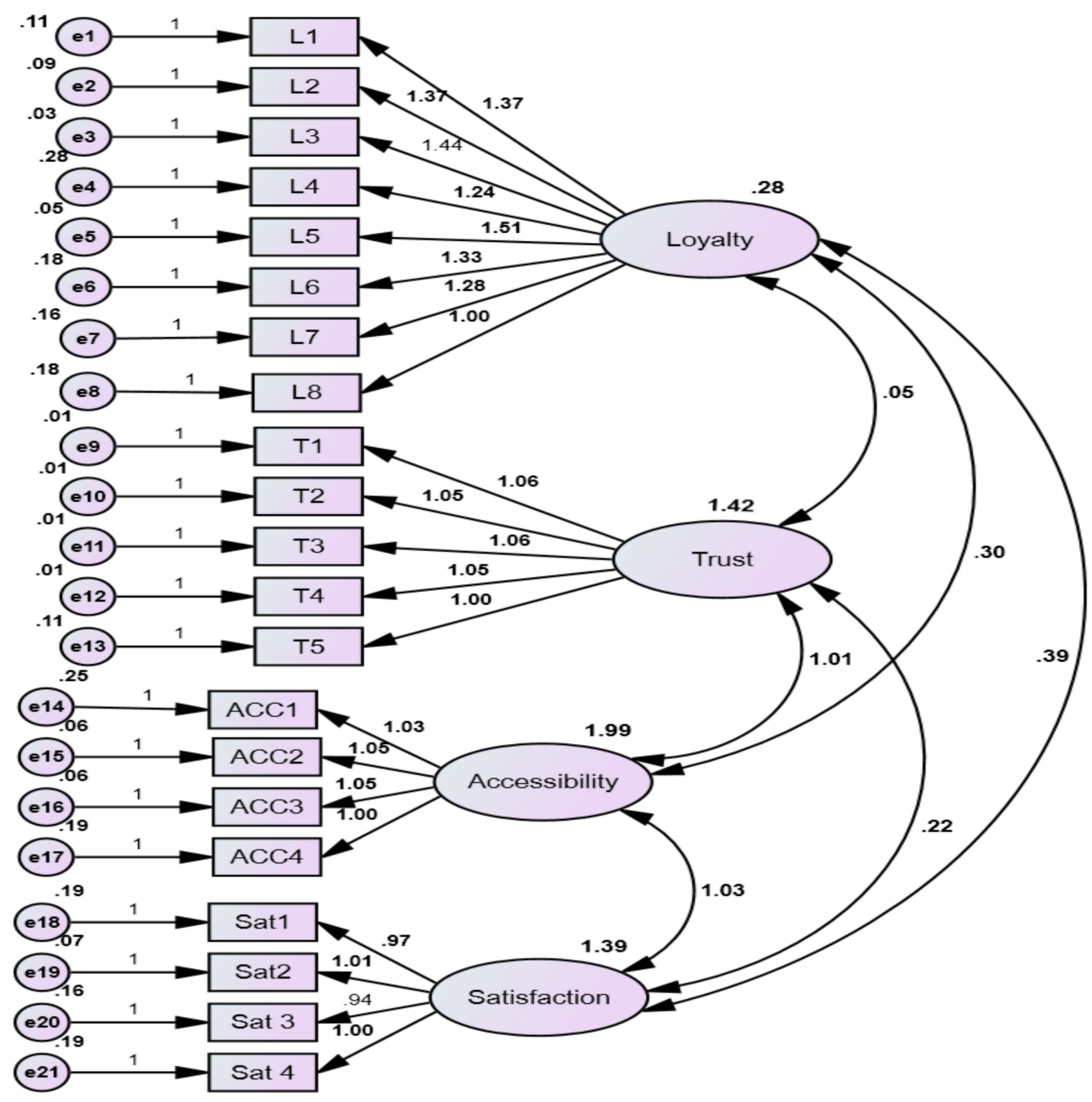

Figure 2. AMOS graphic with the model results (e1-e21 refers to the residual error or error variance that causes response variation in observed variables). 
Furthermore, we show that website accessibility has a direct positive and significant effect on customer satisfaction $(\beta=1.03, p<0.001)$, which means that also Hypothesis 2 is validated. In the case of the relationship between website accessibility and customer trust, the results help us to show a direct positive and significant effect of accessibility on trust $(\beta=1.01, p<0.001)$, therefore, Hypothesis 3 is also validated. The effect of customer satisfaction upon e-loyalty was confirmed as being positive and significant also $(\beta=0.39, p<0.001)$, which is sustaining the validity of Hypothesis 4. The relationship between customer satisfaction and customer trust is shown to be positive and the effect is also significant $(\beta=0.22, p<0.001)$. This supports the validity of Hypothesis 5 . The results regarding the last relationship taken into consideration indicate a direct positive effect of customer trust on e-loyalty $(\beta=0.05, p<0.05)$.

\section{Discussion}

The validation of the advanced hypotheses and the model, as a whole, put in a new light the statements advanced so far. Additionally, the causal relationship highlighted can be seen from the perspective of the specificity of consumption concerning the analyzed products. Our research took into account the consumption of electronic and household appliances. In the case of these products, the consumption needs are expressed quite clearly and the pressure felt by consumers is variable, depending on the concrete purchasing situations. Moreover, compared to other websites intended for purchases related to other types of products and/or services, the accessibility of the site may not have the same significance, as in the case of e-commerce websites dedicated to electronic and household appliances. Buyers of this type of product, once they decide on the preferred model and brand, need a website that is as accessible as much as possible, which will quickly facilitate their ordering and processing/completion. Thus, we have an additional element concerning the already advanced hypotheses, which support the validation of the model and the idea according to which accessibility becomes an essential attribute for the decision-making process and the creation/maintenance of e-loyalty to the site.

The results of the analysis are showing stronger effects between website accessibility and customer satisfaction and, respectively, website accessibility and customer trust, in comparison with the rest of the effects between variables. These results support the idea advanced, that in the case of Romanian consumers and the specific context of consumption for the considered products, website accessibility represents a real driver for satisfaction and trust. The specific situation related to the pressure of the COVID-19 pandemic has determined for Romanian consumers a kind of atypical consumer behavior. A successful approach will consist of investing at the level of the website interface, optimization for mobile payments and order processing, fast, easy navigation through available buying items and strong online support for customers' inquiries or technical problems.

Regarding the limitations and future research, it is important to remember that the sample was composed mainly of people from university campuses-students and master students, and among them, a more significant proportion of respondents have been women who denote a higher propensity to respond. The future research should be extended in the sense of sampling an equilibrated amount of female and male respondents and a greater diversity of consumers from different European countries severely affected by the COVID-19 pandemic (Italy, Spain, France, Greece or Poland) to verify if the proposed model has a cultural and regional bias or can be extended accordingly to different consumption cultures.

\section{Conclusions}

New Internet technologies directly contribute to the expansion of e-commerce, new businesses and e-business models, and the dematerialization of products and services. The Internet is a market for businesses to conquer, an avenue for new opportunities, including by diversifying the services offered and promoting new, personalized and attractive services, which make information and 
communication technologies possible, which stimulates competition and competitiveness by new players in traditional markets.

This article has discussed how the antecedents of e-loyalty have a direct link with the accessibility of the sites and the consumers' perceptions on them. Hence, the study of the perceptual process aims to understand the meaning that an online consumer of electronics and home appliances online stores has from the moment of exposure to sensory stimuli. Likewise, this study on consumer attitudes and their perceptions of e-commerce sites in the Romanian perspective provides, in principle, the direction to find out the antecedents of e-loyalty from a socio-psychological point of view.

According to our findings, future intent to use or to recommend a certain e-commerce website is based on trust and the positive consumption experience optimization, especially in the COVID-19 pandemic context. The level of trust already achieved by the consumers can enhance the capacity to communicate with other consumers and to translate the inner positive attitude to an emotional transfer of trust towards the individuals to whom they are recommending the websites.

Along with previous studies $[27,49,71]$, this study has found that the process of attitude formation can take place on the basis of classical conditioning or on the basis of instrumental conditioning, as well as following a complex cognitive process.

The findings obtained from our empirical research also suggest that the buying decisional process and the outcomes of the behavior in terms of satisfaction levels, and predisposition for trusting the retailers, are changed towards a very practical orientation and the need for fast, reliable buying solutions offered by the online retailers. Implications for online marketing strategies of the retailers are effective and very clear. In fact, Romanian e-business succeeded because it is based on the results of such research, organizing its activity on the principle of adapting the offer to the specifics of consumers. These e-companies first determine the desires of consumers and their willingness to purchase products of a certain quality and then design, manufacture and sell these products at prices that consumers are willing to pay.

From the point of view of our research object, the accessibility of the website becomes an extremely important attribute in the decision-making process of consumers in the conditions created by the new consumption situations against the background of the COVID-19 pandemic. The model also validates the direct and mediated influence of satisfaction on e-loyalty.

Finally, this study would be beneficial for Romanian government bodies and decision-makers, who should develop specific policies to induce sustainable online consumerism. This could be the signal that reflects the sustainability perspective of e-business and is auspicious for improving the reporting of sustainability using IT tools. Furthermore, the results of this study confirm that the social dimension of e-commerce is also related with the link and integration between different types of developed and developing countries as a consequence of commercial exchanges into the online environment.

Author Contributions: Conceptualization, C.A.P., D.A.G. and I.O.; methodology, C.A.P., D.A.G., S.Ș.M. and I.P.G.; validation, C.A.P., I.O., D.A.G., S.S .M., I.P.G. and A.C.M.; formal analysis, C.A.P., I.O., D.A.G., S.Ș.M., I.P.G. and A.C.M.; writing—original draft preparation, C.A.P., I.O., D.A.G., S.S.M., I.P.G. and A.C.M.; writing-review and editing, I.O. All authors have read and agreed to the published version of the manuscript.

Funding: This research received no external funding.

Conflicts of Interest: The authors declare no conflict of interest.

\section{References}

1. Svobodová, Z.; Rajchlová, J. Strategic Behavior of E-Commerce Businesses in Online Industry of Electronics from a Customer Perspective. Adm. Sci. 2020, 10, 78. [CrossRef]

2. Vargo, S.L.; Koskela-Huotari, K.; Baron, S.; Edvardsson, B.; Reynoso, J.; Colurcio, M.A. Systems Perspective on Markets-Toward a Research Agenda. J. Bus. Res. 2017, 79, 260-268. [CrossRef]

3. Pourhejazy, P. Destruction Decisions for Managing Excess Inventory in E-Commerce Logistics. Sustainability 2020, 12, 8365. [CrossRef] 
4. Doligalski, T. Internet Business Models in the Consumer Market-A Typological Approach. Mark. Rynek 2018, 12, 5-13.

5. eMarketer. Available online: www.emarketer.com/forecasts (accessed on 22 May 2020).

6. Gómez-Galán, J.; Martínez-López, J.Á.; Lázaro-Pérez, C.; Sarasola Sánchez-Serrano, J.L. Social Networks Consumption and Addiction in College Students during the COVID-19 Pandemic: Educational Approach to Responsible Use. Sustainability 2020, 12, 7737. [CrossRef]

7. Colla, E.; Lapoule, P. E-commerce: Exploring the Critical Success Factors. Int. J. Retail. Distrib. Manag. 2012, 40, 842-864. [CrossRef]

8. Möhlmann, M. Collaborative consumption: Determinants of satisfaction and the likelihood of using a sharing economy option again. J. Consum. Behav. 2015, 14, 193-207. [CrossRef]

9. Belk, R. You are what you can access: Sharing and collaborative consumption online. J. Bus. Res. 2014, 67, 1595-1600. [CrossRef]

10. Casadesus-Masanell, R.; Ricart, J.E. How to Design a Winning Business Model. Harv. Bus. Rev. 2011, 89, 100-107.

11. Keiningham, T.L.; Vavra, T.G.; Aksoy, L.; Wallard, H. Loyalty Myths: Hyped Strategies that Will Put You Out of Business-And Proven Tactics That Really Work; John Wiley \& Sons: Hoboken, NJ, USA, 2005; pp. 74-76.

12. Chou, S.; Chen, C.; Lin, J. Female online shoppers: Examining the mediating roles of e-satisfaction and e-trust on e-loyalty development. Internet Res. 2015, 25, 542-561. [CrossRef]

13. Bilgihan, A. Gen Y customer loyalty in online shopping: An integrated model of trust, user experience and branding. Comput. Hum. Behav. 2016, 61, 103-113. [CrossRef]

14. Rashid, M.H.U.; Nurunnabi, M.; Rahman, M.; Masud, M.A.K. Exploring the Relationship between Customer Loyalty and Financial Performance of Banks: Customer Open Innovation Perspective. J. Open Innov. Technol. Mark. Complex. 2020, 6, 108. [CrossRef]

15. Anderson, R.E.; Srinivasan, S.S. E-satisfaction and e-loyalty: A contingency framework. Psychol. Mark. 2003, 20, 123-138. [CrossRef]

16. Oláh, J.; Kitukutha, N.; Haddad, H.; Pakurár, M.; Máté, D.; Popp, J. Achieving Sustainable E-Commerce in Environmental, Social and Economic Dimensions by Taking Possible Trade-Offs. Sustainability 2019, 11, 89. [CrossRef]

17. Kikovska-Georgievska, S. E-commerce-challenge for sustainable development of companies. J. Sustain. Dev. 2013, 4, 71-84.

18. Lee, C.-S. An analytical framework for evaluating e-commerce business models and strategies. Internet Res. 2001, 11, 349-359. [CrossRef]

19. Kovács, G.; Kot, S. Economic and social effects of novel supply chain concepts and virtual enterprises. J. Int. Stud. 2017, 10, 237-254. [CrossRef]

20. Hossain, A. E-commerce and sustainability: Concepts, issues and experiences. Pak. J. Inf. Technol. 2002, 1, 188-192.

21. Yoon, Y.; Uysal, M. An examination of the effects of motivation and satisfaction on destination loyalty: A structural model. Tour. Manag. 2005, 26, 45-56. [CrossRef]

22. Nisar, T.M.; Prabhakar, G. What factors determine e-satisfaction and consumer spending in e-commerce retailing? J. Retail. Consum. Serv. 2017, 39, 135-144. [CrossRef]

23. Liu, L.; Xiang, Z.; Liu, Y.; Zach, F.J.; McGehee, N. Factors Influencing Exhibitor Satisfaction and Loyalty: A Meta-Analysis on the Chinese Exhibition Market. Sustainability 2020, 12, 8390. [CrossRef]

24. Ryan, G.; del Mar Pàmies, M.; Valverde, M. WWW = Wait, Wait, Wait: Emotional reactions to waiting on the Internet. J. Electron. Commer. Res. 2015, 16, 261-275.

25. Carneiro, M.J.; Eusébio, C.; Caldeira, A.; Santos, A.C. The influence of events cape on emotions, satisfaction and loyalty: The case of re-enactment events. Int. J. Hosp. Manag. 2019, 82, 112-124. [CrossRef]

26. Cossío-Silva, F.J.; Revilla-Camacho, M.Á.; Vega-Vázquez, M.; Palacios-Florencio, B. Value co-creation and customer loyalty. J. Bus. Res. 2016, 69, 1621-1625. [CrossRef]

27. Bilgihan, A.; Madanoglu, M.; Ricci, P. Service attributes as drivers of behavioral loyalty in casinos: The mediating effect of attitudinal loyalty. J. Retail. Consum. Serv. 2016, 31, 14-21. [CrossRef]

28. Ramaswami, S.N.; Arunachalam, S. Divided attitudinal loyalty and customer value: Role of dealers in an indirect channel. J. Acad. Mark. Sci. 2016, 44, 770-790. [CrossRef] 
29. Ho, C.-W.; Wang, Y.-B. Does Social Media Marketing and Brand Community Play the Role in Building a Sustainable Digital Business Strategy? Sustainability 2020, 12, 6417. [CrossRef]

30. Srinivasan, S.S.; Anderson, R.; Ponnavolu, K. Customer loyalty in e-commerce: An exploration of its antecedents and consequences. J. Retail. 2002, 78, 41-50. [CrossRef]

31. Faraoni, M.; Rialti, R.; Zollo, L.; Pellicelli, A.C. Exploring e-loyalty Antecedents in B2C e-Commerce. Br. Food J. 2019, 121, 574-589. [CrossRef]

32. Martínez-López, F.J.; Pla-García, C.; Gázquez-Abad, J.C.; Rodríguez-Ardura, I. Hedonic motivations in online consumption behaviour. Int. J. Bus. Environ. 2016, 8, 121-151. [CrossRef]

33. Overby, J.W.; Lee, E.J. The effects of utilitarian and hedonic online shopping value on consumer preference and intentions. J. Bus. Res. 2006, 59, 1160-1166. [CrossRef]

34. Bridges, E.; Florsheim, R. Hedonic and utilitarian shopping goals: The online experience. J. Bus. Res. 2008, 61, 309-314. [CrossRef]

35. López, I.; Ruiz, S. Explaining website effectiveness: The hedonic-utilitarian dual mediation hypothesis. Electron. Commer. Res. Appl. 2011, 10, 49-58. [CrossRef]

36. Hazari, S.; Bergiel, B.J.; Sethna, B.N. Hedonic and utilitarian use of user-generated content on online shopping websites. J. Mark. Commun. 2017, 23, 572-591. [CrossRef]

37. Sibony, A.L. The UK COVID-19 Response: A Behavioural Irony? Eur. J. Risk Regul. 2020, 11, 350-357. [CrossRef]

38. Cohen, M.J. Does the COVID-19 outbreak mark the onset of a sustainable consumption transition? Sustain. Sci. Practice Policy 2020, 16, 1-3. [CrossRef]

39. Lee, E.E.; Kang, H.; Ahn, H.J. Word-of-Mouth of Cultural Products through Institutional Social Networks. Sustainability 2017, 9, 917. [CrossRef]

40. He, H.; Harris, L. The Impact of Covid-19 Pandemic on Corporate Social Responsibility and Marketing Philosophy. J. Bus. Res. 2020, 116, 176-182. [CrossRef]

41. Khwaja, M.G.; Mahmood, S.; Zaman, U. Examining the Effects of eWOM, Trust Inclination, and Information Adoption on Purchase Intentions in an Accelerated Digital Marketing Context. Information 2020, 11, 478. [CrossRef]

42. Bilgihan, A.; Sukhu, A.; Kandampully, J. The role of website features in creating loyalty: The mediating effect of commitment. Int. J. Serv. Sci. Manag. Eng. Technol. 2013, 4, 37-50. [CrossRef]

43. Abedi, E.; Ghorbanzadeh, D.; Rahehagh, A. Influence of eWOM information on consumers' behavioral intentions in mobile social networks. J. Adv. Manag. Res. 2019, 17, 84-109. [CrossRef]

44. Le Nguyen, K.D.; Fredrickson, B.L. Positive emotions and well-being. In Frontiers of Social Psychology: Positive Psychology; Dunn, D.S., Ed.; Routledge: New York, NY, USA, 2018; pp. $29-45$.

45. Zhong, Y.; Lai, I.K.W.; Guo, F.; Tang, H. Effects of Partnership Quality and Information Sharing on Express Delivery Service Performance in the E-commerce Industry. Sustainability 2020, 12, 8293. [CrossRef]

46. Behjati, S.; Nahich, M.; Othaman, S.N. Interrelation between E-service Quality and E-satisfaction and Loyalty. Eur. J. Bus. Manag. 2012, 4, 75-85.

47. Lee, S.-J.; Ahn, C.; Song, K.M.; Ahn, H. Trust and Distrust in E-Commerce. Sustainability 2018, $10,1015$. [CrossRef]

48. Kim, D.J. A Study of the multilevel and dynamic nature of trust in e-commerce from a cross-stage perspective. Int. J. Electron. Commer. 2014, 19, 11-64. [CrossRef]

49. Lee, J.; Pee, L.G. The relationship between online trust and distrust in business: Testing mutual causality from a cognitive-affective personality system theory. Asia Pac. J. Inf. Syst. 2015, 25, 500-518. [CrossRef]

50. López-Miguens, M.J.; Vázquez, E.G. An integral model of e-loyalty from the consumer's perspective. Comput. Hum. Behav. 2017, 72, 397-411. [CrossRef]

51. McKnight, D.H.; Choudhury, V.; Kacmar, C. Developing and validating trust measures for e commerce: An integrative typology. Inf. Syst. Res. 2002, 13, 334-359. [CrossRef]

52. Verhagen, T.; Meents, S.; Tan, Y. Perceived risk and trust associated with purchasing at electronic marketplaces. Eur. J. Inf. Syst. 2006, 15, 542-555. [CrossRef]

53. Seckler, M.; Heinz, S.; Forde, S.; Tuch, A.N.; Opwis, K. Trust and distrust on the web: User experiences and website characteristics. Comput. Hum. Behav. 2015, 45, 39-50. [CrossRef]

54. Dabija, D.-C.; Băbut, R. Enhancing Apparel Store Patronage through Retailers' Attributes and Sustainability. A Generational Approach. Sustainability 2019, 11, 4532. [CrossRef] 
55. Vijay, T.S.; Prashar, S.; Sahay, V. The influence of online shopping values and web atmospheric cues on e-loyalty: Mediating role of e-satisfaction. J. Theor. Appl. Electron. Commer. Res. 2019, 14, 1-15.

56. Rodríguez-Ardura, I.; Meseguer, A.; Vilaseca, J. Drivers of online-selling diffusion: A look at organizational and environmental factors through time. In E-Commerce Strategy: Text and Cases; Mohapatra, S., Ed.; Springer: New York, NY, USA, 2012; pp. 243-259.

57. Moody, G.D.; Lowry, P.B.; Galletta, D.F. It's complicated: Explaining the relationship between trust, distrust, and ambivalence in online transaction relationships using polynomial regression analysis and response surface analysis. Eur. J. Inf. Syst. 2017, 26, 379-413. [CrossRef]

58. Dadzie, K.Q.; Chelariu, C.; Winston, E. Customer service in the internet-enabled logistics supply chain: Website design antecedents and loyalty effects. J. Bus. Logist. 2005, 26, 53-78. [CrossRef]

59. Kim, H.W.; Xu, Y.; Gupta, S. Which is more important in Internet shopping, perceived price or trust? Electron. Commer. Res. Appl. 2012, 11, 241-252. [CrossRef]

60. Sullivan, Y.W.; Kim, D.J. Assessing the effects of consumers' product evaluations and trust on repurchase intention in e-commerce environments. Int. J. Inf. Manag. 2018, 39, 199-219. [CrossRef]

61. Bi, Y.; Kim, I. Older Travelers' E-Loyalty: The Roles of Service Convenience and Social Presence in Travel Websites. Sustainability 2020, 12, 410. [CrossRef]

62. Buhalis, D.; López, E.P.; Martinez-Gonzalez, J.A. Influence of young consumers' external and internal variables on their e-loyalty to tourism sites. J. Dest. Mark. Manag. 2020, 15, 1-10. [CrossRef]

63. Koliouska, C.; Andreopoulou, Z.; Zopounidis, C.; Lemonakis, C. E-commerce in the context of protected areas development: A managerial perspective under a multi-criteria approach. In Multiple Criteria Decision Making: Applications in Management and Engineering; Zopounidis, C., Doumpos, M., Eds.; Springer: Berlin, Germany, 2017; pp. 99-111.

64. Gonçalves, R.; Martins, J.; Branco, F. A Review on the Portuguese Enterprises Web Accessibility Levels-A website accessibility high level improvement proposal. Proc. Comput. Sci. 2014, 27, 176-185. [CrossRef]

65. Lee, S.-J.; Choi, S.; Ahn, H. Roles of buyer's trust and distrust in open markets: Focusing on transfer between intermediary and seller. J. Korea Contents Assoc. 2017, 17, 360-374.

66. Chen, Y.H.; Barnes, S. Initial trust and online buyer behavior. Ind. Manag. Data Syst. 2007, 107, 21-36. [CrossRef]

67. Chan, S.H.J.; Wu, S.; Vipulakom, K. Young consumers' behavioral intention based on hotel websites. Anatolia 2020, 31, 1-18. [CrossRef]

68. Bhaskar, P.P.; Kumar, D.P. Customer Loyalty on E-Commerce. Int. J. Manag. Res. Rev. 2016, 6, 1661-1668.

69. Jones, K.; Leonard, L.N.K. Trust in consumer-to-consumer electronic commerce. Inf. Manag. 2008, 45, 88-95. [CrossRef]

70. Serpico, E.; Aquilani, B.; Ruggieri, A.; Silvestri, C. Customer Centric Marketing Strategies: The Importance and Measurement of Customer Satisfaction-Offline vs. Online. In Marketing and Consumer Behavior: Concepts, Methodologies, Tools, and Applications; IGI Global: Hersey, PA, USA, 2015; pp. 666-708.

71. Sohaib, O.; Kang, K.; Nurunnabi, M. Gender-based Trust in E-commerce: The moderating role of cognitive innovativeness. Sustainability 2019, 11, 175.

72. Carter, M.; Wright, R.; Thatcher, J.B.; Klein, R. Understanding online customers' ties to merchants: The moderating influence of trust on the relationship between switching costs and e-loyalty. Eur. J. Inf. Syst. 2014, 23, 185-204. [CrossRef]

73. Romanian Institute for Evaluation and Strategy, Romania in Pandemic-Financial Behavior, Acquisitions and Savings. Available online: https://ires.ro/articol/388/romania-in-pandemie-partea-a-iii-a- (accessed on 7 April 2020).

74. Field, A. Discovering Statistics Using IBM SPSS Statistics, 4th ed.; SAGE Publications Ltd.: London, UK, 2013.

75. Tavakol, M.; Dennick, R. Making sense of Cronbach's alpha. Int. J. Med. Educ. 2011, 2, 53-55. [CrossRef]

76. Kaiser, H.F. An index of factorial simplicity. Psychometrika 1974, 39, 31-36. [CrossRef]

77. Field, A.; Miles, J.; Field, Z. Discovering Statistics Using R; Sage Publications Ltd.: London, UK, 2012.

78. Hooper, D.; Coughlan, J.; Mullen, M. Evaluating model fit: A synthesis of the structural equation modelling literature. In Proceedings of the 7th European Conference on Research Methodology for Business and Management Studies, London, UK, 19-20 June 2008; pp. 195-200.

79. Arbuckle, J.L. IBM SPSS Amos 24 User's Guide, Amos Development Corporation; IBM Corp.: New York, NY, USA, 2016. 
80. Meyers, L.S.; Gamst, G.; Guarino, A.J. Applied Multivariate Research: Design and Interpretation, 3rd ed.; Sage Publications: Los Angeles, CA, USA, 2016; pp. 559-560.

81. Kline, R.B. Principles and Practice of Structural Equation Modeling, 4th ed.; The Guilford Publications: New York, NY, USA, 2015; pp. 314-322.

82. Byrne, B.M. A Primer of LISREL: Basic Applications and Programming for Confirmatory Factor Analytic Models; Springer: New York, NY, USA, 1989; pp. 55-58.

83. Byrne, B.M. Structural Equation Modeling with AMOS: Basic Concepts, Applications, and Programming, 3rd ed.; Taylor \& Francis Group: New York, NY, USA, 2016; pp. 94-98.

Publisher's Note: MDPI stays neutral with regard to jurisdictional claims in published maps and institutional affiliations.

(C) 2020 by the authors. Licensee MDPI, Basel, Switzerland. This article is an open access article distributed under the terms and conditions of the Creative Commons Attribution (CC BY) license (http://creativecommons.org/licenses/by/4.0/). 